\title{
Ladislav Soukup osmdesátníkem
}

V závěru minulého roku se dožil kulatého jubilea stále aktivní doc. JUDr. Ladislav Soukup, CSc. Narodil se dne 19. prosince 1940 v Cetkovicích (severně od Boskovic). Po ukončení stř̌ední školy byl přijat na Právnickou fakultu UK v Praze, kterou úspěšně absolvoval v roce 1963. V roce 1966 získal titul JUDr. a v roce 1982 na podkladě obhajoby práce „Tiskové zákonodárství předmnichovské ČSR“ titul kandidáta věd (k problematice tiskového práva a k souvisícím otázkám se později opakovaně vracel). Docentem v oboru dějiny státu a práva v Československu se stal v roce 1984.

Po absolvování fakulty L. Soukup pracoval jako právní referent někdejšího Ústředního výboru Československého svazu mládeže. V roce 1966 jej akademik Václav Vaněček přijal jako asistenta a posléze odborného asistenta na katedru dějin státu a práva Právnické fakulty UK v Praze. V té době se podílel například na práci Česká národní rada, sněm českého lidu (1970). V roce 1974 přešel na nově zřízenou Vysokou školu SNB, kde stál v čele jejího právněhistorického pracoviště.

Tu si dovolím přerušit tok faktografických informací, protože právě na této škole se protnuly naše životní a profesní dráhy. V té mé profesní, do té doby směřující do právní praxe, to představovalo nejdůležitější odbočení z původně zdánlivě jasně narýsovaného směru.

Když jsem svého pozdějšího dlouholetého nadř́izeného před 45 lety v Holešově viděl poprvé, byl jsem vyjukaný svobodník nebo desátník-absolvent (pro mladší: ten př́idavek k vojenské hodnosti patřil absolventům vysoké školy), kterého krátce předtím ,ppověřili““ výukou právních dějin a římského práva na holešovské fakultě tehdejší policejní školy. Zpočátku jsem vůči němu cítil velký respekt, a proč to nepřiznat, téměř strach. Vždyt' to byla obrovská troufalost, že jsem si - i když ne z vlastní vůle, zato však brzy s vnitřním, ale raději tlumeným uspokojením - troufl bez jakýchkoliv zkušeností, s chatrnými vědomostmi a s vyjadřováním, jež mi komplikovalo již studium, stoupnout před studenty, kteří byli navíc vesměs starší než já (a už vůbec nemluvím o počtu zlatých hvězdiček na výložkách některých z nich). A můj pražský šéf přišel z Karlovy univerzity, jak se rychle po škole rozneslo, tvářil se př́sně a vystupoval velmi odměřeně. Také jedenáctiletý věkový rozdíl, který nás dělí, mi tehdy připadal jako propast. Nic na tom nemění, že jsem v té chvíli ještě netušil, že výuka právních dějin pro mne nebude jen roční epizodou, ale že se právě nepozorovaně nořím do proudu, který mne sice jednou téměř vyplaví na mělčinu, ale jinak celkem plynule ponese až k blížící se sedmdesátce.

Pokud si to dobře uvědomuji, při zmíněné první návštěvě mého pražského nadřízeného v Holešově jsme spolu neprohodili ani větičku. Zajali si jej naši fakultní šéfové, kteří myslím - pocit'ovali k učiteli „,z Karlovky“ podobný respekt jako já. Vždyt' i oni vesměs 
donedávna vysokou školu znali jen ze studentských lavic. Vztah k mému pražskému nadřízenému se postupně měnil, až když se ze mne stal kmenový učitel fakulty. Zpočátku to bylo díky mým poměrně častým služebním cestám do Prahy, at' už jsem primárně směřoval na školu nebo do archivu. V Holešově na mně sice od počátku ležela celá tíha výuky právněhistorických disciplín (když nepočítám počáteční občasnou pomoc externistů), ale dala se s pochopením vedení ve čtrnáctidenních cyklech zorganizovat tak, abych mohl do Prahy jezdit poměrně často. $Z$ obávaného šéfa se postupně stával šéf neobávaný, ale uznávaný, i když př́ísný a důsledný, a po mém pracovním přesunu z Holešova do Prahy i blízký př́itel. Už si nepamatuji, kdy mi nabídl tykání, ale velice dobře si pamatuji, jak dlouho mi trvalo, než jsem si na to zvykl.

Zmíněná prŕísnost mého nadřízeného pramenila především z jeho snahy neuzavírat katedru v bublině naší specifické školy, jako tomu bylo na některých jiných katedrách, a dbát o náš odborný růst. Dělal všechno pro to, abychom pokud možno fungovali jako klasická vysokoškolská katedra a včlenili se do tehdy celkem soudržné a aktivní komunity právních historiků a romanistů. Proto na nás tlačil, abychom se přihlašovali na právněhistorické konference a vystupovali na nich, zúčastňovali se pravidelných setkání československých právních historiků (jedno dokonce naše katedra zorganizovala) i všech akcí pořádaných katedrou pražské právnické fakulty, i formálně si zvyšovali kvalifikaci, chodili do archivů ... A jako jediný skutečný právní historik nám, nezkušeným začátečníkům, radil a také nás povzbuzoval. Pro mne osobně byly jeho odborné rady velmi cenné, a to nejen na počátku, kdy jsem v Holešově, sám vojáček v poli, lovil v paměti vzpomínky na to, co se mi na výuce právních dějin na brněnské fakultě zdálo být dobré a následováníhodné, a co nikoliv, a kdy jsem si začal osahávat pro mne neznámé prostředí archivních badatelen. Mohu s plnou odpovědností napsat, že mne sice i později více či méně ovlivnila a pomohla mi spousta starších i mladších kolegů na čele s nedávno zemřelým prof. Jozefem Klimkem, avšak kdybych měl prstem ukázat na toho, kdo mne naučil právněhistorickou abecedu, míril bych na jeho hrud'.

Abych snad nevytvořil obrázek autoritativního šéfa a jeho na slovo poslušných podřízených, který by možná korespondoval s polovojenským prostředím školy, musím doplnit, že i když př́ikazy také patřily do šéfova repertoáru, rozhodně jimi neplýtval a snažil se na nás působit sice důsledně, ale spíše návodně. Díky tomu se mu rychle podařilo naši věkově i osobním založením velice pestrou katedru stmelit (jen posud’te její pražské jádro: jeden uzavřený a tajemný, druhý bodrý, někdy až nezodpovědný, třetí zemitý, čtvrtý vyjukaný a pátý téměř o generaci mladší než většina ostatních, ale dobře se orientující - $\mathrm{s}$ takovým rozmanitým osazenstvem to neměl jednoduché). I když samozřejmě ne vždy na katedře vše klapalo, jak by mělo, L. Soukup dokázal doutnající konflikty včas eliminovat, takže jsme si v zásadě dobře rozuměli nejen v práci, ale také mimo ni - třeba když jsme čas od času společně vyrazili do večerní Prahy nebo na šéfovu „,pastoušku“, jak říká své tehdy právě zvelebované chalupě.

Když se Vysoká škola SNB transformovala na Policejní akademii a z jejích vyučovacích plánů výuka právních dějin vypadla, doc. Soukup se jako vědecký pracovník vrátil na pražskou Právnickou fakultu. Začal vykonávat i advokátní praxi a později též externě vyučovat na Fakultě právnické ZČU v Plzni.

Na pražské právnické fakultě spolu s prof. Karlem Malým spoluzakládal Ústav právních dějin, kde působil až do jeho nedávného zániku. Stal se zde tajemníkem a z toho titulu 
výkonným redaktorem Právněhistorických studií (do č. 47/2), členem jejich redakční rady, spoluorganizátorem velkých mezinárodních konferencí ze začátku jednadvacátého století a také spolueditorem z nich vzešlých sborníků (Přispěvky $k$ vývoji právního ř́du v Československu 1945-1989 z roku 2002, Vývoj práva v Československu v letech 1945-1989 z roku 2004, Vývoj české ústavnosti v letech 1618-1918 z roku 2006, dvoudílné Československé právo a právní věda v meziválečném obdobi a jejich misto ve střední Evropě z roku 2010). Jako spoluřešitel se podílel též na grantovém úkolu GA ČR Vladislavské zř́zení zemské (ukončeno 2000). Ústav považoval a považuje, podobně jako prof. Malý, svým způsobem za svůj, a tak zánik jeho samostatnosti pocit’uje jako velkou ránu (Ústav právních dějin se v prosinci 2019 sloučil s Katedrou právních dějin PFUK - pozn. red.).

Na pražské fakultě se doc. L. Soukup dále podílí na výuce Historických základů českého práva a vyučuje a garantuje Právní dějiny UK a Vědecký seminár̆: České a československé právní dějiny. Je spoluautorem pražských učebnic českých právních dějin i učebních pomůcek pro plzeňskou právnickou fakultu. V roce 1995 uspořádal Poctu prof. JUDr. Karlu Malému, DrSc., k 65. narozeninám a v roce 1993 spolu s P. Skřejpkovou Antologii české právní vědy (2. polovina 19. století až 30. léta století 20.). S kolegy z ústavu a katedry připravil např́klad Dějiny českého soudnictví od počátkủ české státnosti do roku 1938 (2005) a v širokém kolektivu Práva městská Království českého: edice s komentářem (2013). Je spoluautorem dalších monografií (například Nové jevy v právu na počátku 21. století I. Historické impulzy rozvoje práva z roku 2009 nebo s P. Skřejpkovou Nedemokratické právní systémy ve vybraných státech Evropy první poloviny 20. století z roku 2011), a publikoval spoustu studií v odborných časopisech, velmi často v Právněhistorických studiích, a prŕíležitostných sbornících. Několika hesly přispěl do Encyklopedie českých právních dějin.

Dnešní specifická doba většině z nás zabránila, abychom oslavenci potřásli rukou a z očí do očí popřáli. Proto, a aby závěrečné přání směřovalo, jak se sluší a patří, k oslavenci, dovolím si nejdříve poprrát sobě, at’ už brzy mohu v Praze na fakultě zase zaklepat na dveře s jeho jmenovkou. Doufám, že mne v nich uvidí rád, já jej v jeho křesle určitě.

A ted' tedy alespoň na dálku a jistě nejen za redakční radu Právněhistorických studií a za sebe: pevné zdraví a chut'stále a stále si ověrovat, že slečna právni historie je děvčica pěkná, žádoucí a inspirativni!!

Ladislav Vojáček

doi: 10.14712/2464689X.2021.9 